\title{
UNDERSTANDING THE FEELINGS AND MOTIVATION OF AFGHAN STUDENTS' REGARDING STUDYING AT CHINESE UNIVERSITIES
}

\author{
Hizbullah Bahir \\ Master Degree Student \\ Beijing Sport University, Beijing, China \\ Teaching Assistant \\ Physical Education Department \\ Education Faculty, Kandahar University \\ Kandahar, Afghanistan \\ E-mail: bahir.hizbullah@ @otmail.com \\ Huanghe \\ Associate Professor \\ Competitive Education Department \\ Competitive Sport Faculty, Beijing Sport University \\ Beijing, China \\ E-mail: Huanghexx@126.com
}

\begin{abstract}
Making a decision to study in foreign countries is considered one of the most difficult tasks. However, it is one of the most essential and valuable attempts for the students because in foreign countries the quality of lessons are high and they can make huge social relations with learners. Also, China accepts students from all over the world. This study examined the feelings, and motivations of Afghan students; the data was collected through google form and constructed interview which 99 students were the participants. A mixed approach was used for this study. Moreover, the interview was done with those learners who have been completed their higher education in the country of China and the data was analyzed through SPSS 26 version. The findings asserted that learning of students in China is very beneficial as well with the relations of other foreign countries who study in China. Furthermore, the findings indicated more that learners have noticeable achievements in the parts of the culture of China, new technology; learning of Chinese language. Additionally, in China living allowance, medical services, wellequipped dormitories and the services of seeing historical places are free of charge for the better life of students.
\end{abstract}

Keywords: Motivation, Feelings, Studying Abroad, Afghan Students.

JEL Classification Codes: A19, B10, B25, C10, C53.

\section{INTRODUCTION}

Many students choose to study in foreign countries because of the possible advantages. Study in abroad will meet the expectations of your university degree and traveling around the world while at the same time exploring new cultures. Afghan students try to pursue higher education in 
abroad but many students do not know which problems they will face, and how the new the culture, religion, language and so on will affect them. A choice to study in abroad is not just a difficult decision-making process for students (Mazzarol, 1998). At the same time, a student undertakes one of the most critical and costly projects, take into account all the difficulties of studying in abroad and have a specific plan for it. (Sirowy \& Inkeles, 1984; McMahon, 1992; Mazzarol \& Soutar, 2002). In these years, the Ministry of Higher Education of Afghanistan tries to find an opportunity for students in foreign countries which one of these countries is a friendly country of China. Every year hundreds of Afghan students go for higher education to China. In 2008, thirty-six Afghan learners were busy on their studies in China. Right now, hundreds of learners choose Chines universities only from Afghanistan. This current research expands on studying in abroad motives and benefits and attempts to explore the particular motivations that could affect Afghan students' decision to study in China country. Understanding what motivates and honors the students to study in China gives institutions of higher education knowledge to help prospective students and inspire them to study.

\section{PROBLEM STATEMENT}

In recent years, many Afghan students want to study in foreign countries; however, there are very limited studies conducted in Afghanistan regarding the feelings and motivation. The International Education Institution states that the aim is to enhance substantially the number of foreign students studying in China but little research conducted into what the foreign students do to exchange experiences in China (Belyavina, 2013). In addition, there are not reputable sources for students in order to get benefit from them as sources. Moreover, students who want to study higher education in China have many questions because of not having suitable sources. Whereas China is one of those countries that accept Afghan students in different fields, but the problem is that they do not have information about the culture, language and universities of China. This available source would assist them to answer their queries.

\section{Research Objectives}

- To identify the main factors that makes Afghan students to choose China for higher education.

- To clarify the benefits that Afghan students get in China in terms of culture and language.

- To investigate the evidence that has still proved to be very useful for Afghan students.

\section{Research Questions}

- What are the factors that make Afghan students to choose China for higher education?

- What are the benefits that Afghan students get in China in terms of culture and language?

- What are the evidence that has still proved to be very useful for Afghan students?

\section{LITERATURE REVIEW}

The literature refers to a variety of motivating forces responsible for drawing students to the host country. Economic relations between the domestic country and the host country, the scale of the economy of the home country relative to that of the host country, the involvement of the host country in the home country through foreign assistance or cultural links and scholarships and other forms of assistance, international acceptance of qualifications from Western institutions of higher education (McMahon, 1992). In encouraging research on board programs to prospective candidates, educational priorities, such as being fluent in a foreign language, observing a new teaching process, improving job prospects and competition, and learning about a subject not 
offered at a homeland university, play a significant role (Teichler \& Steube, 1991; Himat, 2020). The value of study in abroad has been known for a long time. Educators, policymakers, and business leaders have all realized the need for young people to have been global experienced (MCGiffert, 2011). Study programs in abroad offer university students greater global expertise, expanded horizons, and the ability to learn foreign cultures and languages. Unfortunately, minority Afghan students study in abroad (Smith \& Mitry, 2008). In fact, it is a priority for many states to provide opportunities for students to study in abroad. (MC Giffert, 2011).

The Government of Afghanistan provides many opportunities for students to study inside the country. As well as trying to send students into foreign countries for higher education, to stay competitive in today's world, students must study internationally, learn the languages of other countries try to reduce distances in order to increase international relations promote formal education abroad and improve their potential job view to do (Smith \& Mitry, 2008; Sahibzada \& Himat, 2019; Bahir, 2020). China is a friend country of Afghanistan committed to cooperation and provides higher education for Afghan students. The higher education system established in China, (excluding Hong Kong, Macao, and Taiwan) Provides scholarships for foreign universities and scholarships for international students which attract thousands of students internationally every year (Hennock, 2012; Goodman, 2011). At present, China accepts hundreds of Afghan students every year for higher education (Belyavina, 2013). Universities leaders and political figures are committed to creating exchanges between peoples and countries. Under this program, the governments of Afghanistan and China are committed to increasing the number of Afghan students in China.

The motivation was described for this study as factors that influence a decision of students to study in abroad (Jolibert \& Baumgartner, 1997). Research on reasons for studying in abroad deals whether the students want to study in abroad or not. The choice to study in abroad involves both the positive and the negative aspects and their feelings about studying in abroad push and pull factors (Doyle, 2009; Goel, De Jong, \& Schnusenberg, 2010; Himat \& Nazari, 2019; Nazari \& Himat, 2020). It was decided in the study (Sánchez, Fornerino \& Zhang 2006) that certain factors were used in the option to study in abroad to obtain a new experience, improve the condition of working, improve the social situation, seek freedom/pleasure, learn new languages.However, the following barriers could be family barriers, finance barriers, psychological barrier and social barriers. These factors discourage students to studying in abroad (Himat \& Nazari, 2021).

Study in China can bring various benefits to the students in the areas of ranging from language development to growing their cross-cultural experience. These advantages are different for any student and can vary based on the specific study venue. Analysis indicates the possible advantages of study in abroad act as incentives (Doyle, 2009). The returning students bring with them the experience of cultural understanding, personal development possible opportunities for higher education, achievements of Second language skill, close friendship with local people socialization and globalization because in foreign then get will acquaintance with technology as well (Smith \& Mitry, 2008; Himat, Takal \& Hakimi, 2021).

\section{RESEARCH METHDOLOGY}

This study used a quantitative research method. In addition, 99 Afghan students have been taking part among these 68 were male and one female student who have answered the questionnaires, and with 30students have interviewed those who had already graduated from Chinese universities. The present study used survey methods in order to explore and evaluate Afghan 
students who have studied or currently studying in China. Convenient and snowball sampling was used to recruit subjects. An online survey was the main source for collecting the data of this research. The data was collected from those students who were graduated from several programs of Chines Universities such as $\mathrm{PhD}$, Master and Bachelor Degrees. The data was analyzed with SPSS version 26.

\section{FINDINGS}

Table 1. Shows the demographic data of the participants

\section{Demographic Data of the Respondents}

\begin{tabular}{|l|l|l|l|}
\hline \multicolumn{2}{|l|}{ Characteristics } & Frequency & Percentage \\
\hline \multirow{3}{*}{ Gender: } & Male & 68 & $98.6 \%$ \\
\cline { 2 - 4 } & Female & 1 & $1.4 \%$ \\
\hline \multirow{3}{*}{ Level of Education: } & Bachelor & 4 & $5.4 \%$ \\
\cline { 2 - 4 } & Master & 50 & $72.5 \%$ \\
\cline { 2 - 4 } & Ph.D. & 15 & $21.7 \%$ \\
\hline \multirow{3}{*}{ Teaching language } & Ahinese $:$ & 18 & $26.1 \%$ \\
\cline { 2 - 4 } & English & 51 & $73.9 \%$ \\
\hline \multirow{3}{*}{ Age: } & Between 21\&26 & 8 & $11.6 \%$ \\
\cline { 2 - 4 } & Between 27\&32 & 41 & $59.4 \%$ \\
\cline { 2 - 4 } & $33-$ Upper & 20 & $29.0 \%$ \\
\hline
\end{tabular}

Table 1, the characteristics of the respondents in this study are as below, 68(98.6\%) male, $1(1.4 \%)$ female, the categories of their education are 4(5.4\%\%) Bachelor, 50(72.5\%) Master, 15(21.7\%) Ph.D., this means that a large number of Bachelor degree physical education professionals participated in the study, the ages of the respondents are between the following years, 8(11.6\%) Between 21\&26 years, 41(59.4\%) Between 27\&32years, 20(29.0\%) 33- Upper, the age categories show that most of the respondents were between $27 \& 32$ years old.

Table 2. Shows the views of Afghan students in China

\begin{tabular}{|c|l|c|c|c|c|}
\hline \multicolumn{2}{|c|}{ Items } & Disagree & Agree & Frequency & Percent \\
\hline Valid & $\begin{array}{l}\text { Have you studied at Higher } \\
\text { Education Institution before } \\
\text { coming to China }\end{array}$ & $\begin{array}{c}9 \\
(13.0 \%)\end{array}$ & $\begin{array}{c}60 \\
(87.0 \%)\end{array}$ & 69 & $100.0 \%$ \\
\hline
\end{tabular}




\begin{tabular}{|l|l|c|c|c|c|}
\hline $\begin{array}{l}\text { If other Afghans require advice } \\
\text { from you regarding choosing } \\
\text { China for getting higher } \\
\text { education, what will be your } \\
\text { response to them }\end{array}$ & $\begin{array}{c}\text { (4.3\%) } \\
(95.7 \%)\end{array}$ & 69 & $100.0 \%$ \\
\hline
\end{tabular}

Table 2 Shows the views of Afghan students in China, the first question was: Have did you study at a higher Educational Institution before coming to China, the respondents 60(87.0\%) persons are agree and $9(13.0 \%)$ persons are disagree, as a conclusion the survey showed that most of them were agreed. If others Afghans need your advice regarding to choose China for higher education, what will be your responsibility to the respondent 66(95.7\%) persons were agree and 3(4.3\%) persons were disagree, the answers showed that most of them agreed.

Table 3. Shows the percentage of learning the Chinese language

\begin{tabular}{|l|c|c|c|c|c|}
\hline Frequency & 37 & 13 & 9 & 8 & 2 \\
Percent & $(53.6 \%)$ & $(18.8 \%)$ & $(13.0 \%)$ & $(11.6 \%)$ & $(2.9 \%)$ \\
\hline
\end{tabular}

Table 3 Shows the percentage of learning the Chinese language from 69 respondents 37 students $(53.6 \%)$ were agree, 13 students $(18.8 \%)$ were agree, 9 persons $(13.0 \%)$ were agree, 8 students $(11.6 \%)$ were agree, $2(2.9 \%)$ were agree, Respondents answers also showed that they were at least familiar with the Chines language.

Table 3.Shows the teaching and learning

\begin{tabular}{|c|l|c|c|c|c|c|}
\hline No & \multicolumn{1}{|c|}{ Items } & Agree & Disagree & Neutral & $\begin{array}{c}\text { Strongly } \\
\text { Agree }\end{array}$ & $\begin{array}{c}\text { Strongly } \\
\text { Disagree }\end{array}$ \\
\hline 1 & $\begin{array}{l}\text { At the University where you are } \\
\text { a student, Do they support you }\end{array}$ & $\begin{array}{c}31 \\
(44.9 \%)\end{array}$ & $\begin{array}{c}1 \\
(1.4 \%)\end{array}$ & $\begin{array}{c}7 \\
(10.1)\end{array}$ & $\begin{array}{c}28 \\
(40.6 \%)\end{array}$ & $\begin{array}{c}2 \\
(2.9 \%)\end{array}$ \\
\hline 2 & $\begin{array}{l}\text { How is the culture of the } \\
\text { Chinese to you }\end{array}$ & $\begin{array}{c}35 \\
(50.7 \%)\end{array}$ & 0 & 14 & 20 & 0 \\
\hline 3 & $\begin{array}{l}\text { Teachers use different } \\
\text { technique for encouraging us. }\end{array}$ & $\begin{array}{c}32 \\
(46.4)\end{array}$ & $\begin{array}{c}20.3 \%) \\
(29 \%)\end{array}$ & 14 & 20 & 1 \\
\hline 4 & $\begin{array}{l}\text { In all, I am satisfied from the } \\
\text { teaching process. }\end{array}$ & $\begin{array}{c}32 \\
(46.4 \%)\end{array}$ & $\begin{array}{c}3 \\
(4.3 \%)\end{array}$ & $\begin{array}{c}10 \\
(14.5 \%)\end{array}$ & $\begin{array}{c}22 \\
(31.9 \%)\end{array}$ & $\begin{array}{c}2 \\
(2.9 \%)\end{array}$ \\
\hline
\end{tabular}

Table 3. Shows the teaching and learning, at the University where you are student, do they support you? From 69 respondents $31(44.9 \%)$ were agree, $1(1.4 \%)$ were Disagree, $7(10.1 \%)$ were Neutral, $28(40.6 \%)$ were Strongly Agree, 2(2.9\%) were Strongly Disagree, Most students were strongly agree. How the culture of the Chinese to you is $35(50.7 \%)$ were agree, 14(20.3 $\%)$ were Neutral, 20 (29.0\%) were strongly agreed, as a result most of the students were agreed. Teachers use different techniques for encouraging us.32 (46.4\%) were agree, $2(2.9 \%)$ were Disagree, 14(20.3\%) were Neutral, 20 (29.0\%) were Strongly Agree, 1(1.4\%) were Strongly Disagree, Most students agree. In all, I am satisfied with the teaching process.32 (46.4\%) were 
agree, 3 (4.3\%) were Disagree, 10(14.5\%) were Neutral, 22 (31.9 \%) were Strongly Agree, 2(2.9\%) were Strongly Disagree, Most students were agree.

Table 4. Shows the workload and assessment

\begin{tabular}{|c|c|c|c|c|c|c|}
\hline No & Items & Agree & Disagree & Neutral & $\begin{array}{c}\text { Strongly } \\
\text { Agree }\end{array}$ & $\begin{array}{l}\text { Strongly } \\
\text { Disagree }\end{array}$ \\
\hline 1 & $\begin{array}{l}\text { At the beginning of each } \\
\text { semester, we get } \\
\text { awareness about each } \\
\text { subject. }\end{array}$ & $\begin{array}{c}34 \\
(49.3 \%)\end{array}$ & $\begin{array}{c}4 \\
(5.8 \%)\end{array}$ & $\begin{array}{c}8 \\
(11.6 \%)\end{array}$ & $\begin{array}{c}23 \\
(33.3 \%)\end{array}$ & 0 \\
\hline 2 & $\begin{array}{l}\text { The workload of teaching } \\
\text { is fair to me. }\end{array}$ & $\begin{array}{c}37 \\
(53.6 \%)\end{array}$ & $\begin{array}{c}3 \\
(4.3 \%)\end{array}$ & $\begin{array}{c}12 \\
(17.4 \%)\end{array}$ & $\begin{array}{c}15 \\
(21.7 \%)\end{array}$ & $\begin{array}{c}2 \\
(2.9 \%)\end{array}$ \\
\hline 3 & Do you study much & $\begin{array}{c}32 \\
(46.4 \%)\end{array}$ & $\begin{array}{c}1 \\
(1.4 \%)\end{array}$ & $\begin{array}{c}5 \\
(7.2 \%) \\
\end{array}$ & $\begin{array}{c}31 \\
(44.9 \%)\end{array}$ & 0 \\
\hline 4 & $\begin{array}{l}\text { Teachers always give us } \\
\text { teaching materials for the } \\
\text { improvement of our } \\
\text { educational field. }\end{array}$ & $\begin{array}{c}25 \\
(36.2 \%)\end{array}$ & $\begin{array}{c}2 \\
(2.9 \%)\end{array}$ & $\begin{array}{c}13 \\
(18.8 \%)\end{array}$ & $\begin{array}{c}28 \\
(40.6 \%)\end{array}$ & $\begin{array}{c}1 \\
(1.4 \%)\end{array}$ \\
\hline
\end{tabular}

Table 4. Shows the Workload and assessment, at the beginning of each semester, we get awareness about each subject. From 69 respondents $34(49.3 \%)$ were agree, 4 (5.8 \%) were Disagree, 8(11.6\%) were Neutral, $23(33.3 \%)$ were Strongly Agree, most of the students were Agree. The workload of teaching is fair for me.37 (53.6\%) were agree, 3 (4.3\%) were Disagree, 12(17.4\%) were Neutral, $15(21.7 \%)$ were Strongly Agree, 2(2.9\%) were strongly disagree most students were agree. Do you study too much $32(46.4 \%)$ were agree, $1(1.4 \%)$ were Disagree, 5(7.2 \%) were Neutral, $31(44.9 \%)$ were Strongly Agree, Disagree most students Agree. Teachers always give us teaching materials for the improvement of our educational purposes 25(36.2\%) were agree, $2(2.9 \%)$ were Disagree, 13(18.8\%) were Neutral, $28(40.6 \%)$ were Strongly Agree, 1(1.4\%) were Strongly Disagree most students were Agree.

Table 5. Shows the support and services

\begin{tabular}{|c|c|c|c|c|c|c|}
\hline No & Items & Always & Never & Often & Rarely & Sometimes \\
\hline 1 & $\begin{array}{l}\text { China provides the best } \\
\text { services for foreign students. }\end{array}$ & $\begin{array}{c}36 \\
(52.2 \%)\end{array}$ & $\begin{array}{c}2 \\
(2.9 \%)\end{array}$ & $\begin{array}{c}21 \\
(30.4 \%)\end{array}$ & $\begin{array}{c}2 \\
(2.9 \%)\end{array}$ & $\begin{array}{c}8 \\
(11.6 \%)\end{array}$ \\
\hline 2 & $\begin{array}{l}\text { Do you get to benefit from the } \\
\text { health center of the university? }\end{array}$ & $\begin{array}{c}12 \\
(17.4 \%)\end{array}$ & $\begin{array}{c}15 \\
(21.7 \%)\end{array}$ & $\begin{array}{c}19 \\
(27.5 \%)\end{array}$ & $\begin{array}{c}8 \\
(11.6 \%)\end{array}$ & $\begin{array}{c}15 \\
(21.7 \%)\end{array}$ \\
\hline 3 & $\begin{array}{l}\text { Do you get to benefit from the } \\
\text { library of the university? }\end{array}$ & $\begin{array}{c}33 \\
(47.8 \%)\end{array}$ & $\begin{array}{c}5 \\
(7.5 \%)\end{array}$ & $\begin{array}{c}17 \\
(24.6 \%)\end{array}$ & $\begin{array}{c}5 \\
(7.2 \%)\end{array}$ & $\begin{array}{c}9 \\
(13.0 \%)\end{array}$ \\
\hline
\end{tabular}

Table 5. Shows support and services, China provides the best services for foreign students. From 69 respondents36 (52.2\%) were always, $2(2.9 \%)$ were Never, 21(30.4\%) were often, $2(2.9 \%)$ were rarely Agree, $8(11.6 \%)$ were sometimes, most student the respondents always. Do you get 
to benefit from the health center of the university? $12(17.4 \%)$ were always, $15(21.7 \%)$ were never, $19(27.5 \%)$ were often, $8(11.6 \%)$ were rarely agree, $15(21.7 \%)$ were sometimes, most student the respondents never. Do you get to benefit from the library of the university? 33 (47.8 $\%)$ were always, $5(7.5 \%)$ were never, $17(24.6 \%)$ were often, $5(7.5 \%)$ were rarely agree, $9(13.0 \%)$ were sometimes, most student the respondents always.

Table 6. Shows the achievements of students besides learning

\begin{tabular}{|l|l|c|c|}
\hline \multicolumn{2}{|c|}{ Items } & Frequency & Percent \\
\hline Valid & Acquaintance with Chines and their culture & 22 & 31.9 \\
\cline { 2 - 4 } & Get information about the friendship in programs & 5 & 7.2 \\
\cline { 2 - 4 } & Make relations with international students & 34 & 49.3 \\
\cline { 2 - 4 } & $\begin{array}{l}\text { We give information to international students about } \\
\text { culture as well as cultural values }\end{array}$ & 8 & 11.6 \\
\hline
\end{tabular}

Table 6. Shows extra achievements besides learning, Acquaintance with Chines and their culture, From 69 respondents $22(31.9 \%)$, got information about the friendship in programs5 (7.5\%), we gave information to international students about culture as well as cultural values $(8(11.6 \%)$. majority respondents choose china for its international relations and the minority of them for its culture.

Table 7. Shows the Chinese research decision factors

\begin{tabular}{|l|l|c|c|}
\hline \multicolumn{1}{|c|}{ Items } & Frequency & Percent \\
\hline Valid & Financial values & 14 & 20.3 \\
\cline { 2 - 4 } & In the interest of family a friends & 6 & 8.7 \\
\cline { 2 - 4 } & Past or old information about China & 23 & 33.3 \\
\cline { 2 - 4 } & Physical environment & 3 & 4.3 \\
\cline { 2 - 4 } & Social environment & 5 & 7.2 \\
\cline { 2 - 4 } & Social values & 14 & 20.3 \\
\cline { 2 - 4 } & The readiness of a physical environment & 4 & 5.8 \\
\hline
\end{tabular}

Table 7. Shows the Chinese research decision factors, From 69 respondents, financial values 14 $(20.3 \%)$, In the interest of family friend's 6(8.7\%), Pastor old information about China(23(33.3\%), Physical Environment(3(4.3\%) Social environment (5(7.2\%), Social values (14(20.3\%), the readiness of a physical environment4 (5.8\%), most respondents Past or old information about China were agree. 
Table 8. Shows the advantages of studying in China

\begin{tabular}{|l|l|c|c|}
\hline \multicolumn{2}{|c|}{ Items } & Frequency & Percent \\
\hline \multirow{7}{*}{ Valid } & Cultural benefits & 6 & 8.7 \\
\cline { 2 - 4 } & $\begin{array}{l}\text { Friendly relationships of Chines and their delicious } \\
\text { food }\end{array}$ & 2 & 2.9 \\
\cline { 2 - 4 } & Getting economic opportunities & 2 & 2.9 \\
\cline { 2 - 4 } & Good management of Chines authorities & 3 & 4.3 \\
\cline { 2 - 4 } & Learning of Chines language & 14 & 20.3 \\
\cline { 2 - 4 } & $\begin{array}{l}\text { Opportunities for bachelor, master, and doctorate } \\
\text { degrees in professional departments }\end{array}$ & 25 & 36.2 \\
\cline { 2 - 4 } & $\begin{array}{l}\text { Readiness for future life to live on an international } \\
\text { level. }\end{array}$ & 17 & 24.6 \\
\hline
\end{tabular}

Table 8. Shows the Advantages of studying in China, Cultural benefits, From 69 respondents $6(8.7 \%)$, Friendly relationships of Chines and their delicious food 2(2.9\%), Getting economical opportunities2 (2.9\%), Good management of Chines authorities3 (4.3\%), Learning of Chinese language 14 (20.3\%), Opportunities for bachelor, master, and doctorate degrees in professional departments, 25(36.2\%), Readiness for future life to live on an international level17 (24.6\%). Most students Opportunities for bachelor, master, and doctorate degrees in professional departments choose.

Table 9. Shows the familiarity of students with new technology

\begin{tabular}{|l|c|c|c|c|c|c|}
\hline Frequency & 5 & 11 & 27 & 20 & 6 & Total \\
\hline Percentage & $(7.2 \%)$ & $(15.9 \%)$ & $(39.1 \%)$ & $(29.0 \%)$ & $(8.7 \%)$ & $69(100.0 \%)$ \\
\hline
\end{tabular}

Table 9 Shows the familiarity of Afghan learners with new technology, from 69 respondents, $5(7.2 \%)$ were agree, 11(15.9\%) were agree, $27(39.1 \%)$ were agree, 20(29.0\%) were agree , 6 $(8.7 \%)$ were agree, it clear from the respondents that they are only $80 \%$ familiar with bringing about significant positive change in the field of technology for Afghanistan.

\section{DISCUSSION}

The responses to afghan student's feelings and motivations for studying at Chines universities revealed that many Afghan students are going to China to complete their higher education. There are no master's and PhD programs in some academic fields such as journalism, physical education, and Social Sciences. The other reason is low quality education at Afghan universities, while the Chinese universities have high quality. Because of high quality Afghan students choose China for higher education. The results of the survey show me that Chines scholarships have proved to be very useful for Afghan students not only in the field of excellence in education but also in relations with international students Chinese culture new technologies and Chines language learning. Afghan students have significant achievements so through this experience 
Afghan students can better benefit from living a better life in the world and becoming acquainted with the cultures of different countries, as well as having these skills Afghan students can, establish economic social and scientific ties between Afghanistan and China.

The sentiments of Afghan students show that China is a country that respects the beliefs of all ethnic groups. All foreign students are treated the same as chines at in Chines universities, and every Chinese university has dining rooms for Halal food. The survey found that $95 \%$ of Afghan students feel good about China. As noted in the study that studying abroad help students to live and work abroad in the future (Smith \& Friends, 2008). The student responses present that Afghan students are also pursuing related goals so that they can live and work in abroad in the future. As Doyle, in her 9-year study found that learning in China is very useful in terms of the Chinese language and culture that Afghan students have achieved the same goals. His lessons were in Chines, he has learned Chines and is well familiar with Chines culture.

\section{RECOMMENDATIONS FOR FURTHER STUDIES}

It will be great importance to draw on studies to consider student improvements overtime when adjusting to China (both psychological and socio-cultural). Besides, it would be important to see what factors could affect students' decisions to return home early. The study also needs to investigate the academic adaptation of Afghan students to study in China. Some of the best perspectives can be obtained by conducting a longitudinal analysis that can assess the academic performance of international students relative to local Chines students. What sorts of stress or problems do students face in the same way? Further research can also benefit from researching individuals who want to incorporate or assimilate relative to individuals who choose to spend time with other international students only. For example, a fascinating analysis could compare two groups of students studying where one group has a Chines roommate and one group has an Afghan roommate. This style of study design will help researchers decide if this living aspect has any effects on a student's ability to learn Chines Mandarin and to change or develop their sociocultural adaptation. In conclusion, more qualitative and quantitative analysis needs to be carried out to consider the experience of international students and how to inspire more students to study in the People's Republic of China.

\section{REFERENCES}

Bahir, H. (2020). The Role of Sports on the Development of Tribes Unity: Afghan Society, Kabul, Afghanistan. American International Journal of Social Science Research, 5(3), 53-56.

Belyavina, R. (2013). US students in China: Meeting the goals of the 100,000 strong initiatives. New York: Institute of International Education.

Doyle, S., Gendall, P., Meyer, L. H., Hoek, J., Tait, C., McKenzie, L., \& Loorparg, A. (2010). An investigation of factors associated with student participation in study abroad. Journal of Studies in International Education, 14(5), 471-490. https://doi.org/10.1177\%2F1028315309336032

Eder, J., Smith, W. W., \& Pitts, R. E. (2010). Exploring factors influencing student study abroad destination choice. Journal of Teaching in Travel \& Tourism, 10(3), 232-250. https://doi.org/10.1080/15313220.2010.503534 
Goel, L., De Jong, P., \& Schnusenberg, O. (2010). Toward a comprehensive framework of study abroad intentions and behaviors. Journal of Teaching in International Business, 21(4), 248-265. https://doi.org/10.1080/08975930.2010.526011

Goodman, A., \& Institute of International Education. (2011). US-China student exchange. IIE Passport Study Abroad in China, 5.

Hennock, M. (2012). China Rolls Out the Welcome Mat for Foreign Students. Chronicle of Higher Education. https://eric.ed.gov/?id=EJ992224

Himat, A. N. (2020). The Effects of Facebook on Students' Social Life: A Case Study at Mirwais Khan Nika Zabul Institute of Higher Education, Zabul. American International Journal of Social Science Research, 5(3), 7-16.https://doi.org/10.46281/aijssr.v5i3.593

Himat, A. N., \& Nazari, H. R. (2019). INVESTIGATING THE LEVEL OF TEST ANXIETY IN EFL STUDENTS'AT KANDAHAR UNIVERSITY, AFGHANISTAN. European Journal of English Language Teaching.http://dx.doi.org/10.46827/ejel.v0i0.2475

Himat, A. N., \& Nazari, H. R. (2021). AFGHAN STUDENTS'PURPOSES OF USING FACEBOOK AT MIRWAIS KHAN NIKA ZABUL INSTITUTE OF HIGHER EDUCATION, ZABUL, AFGHANISTAN. American International Journal of Social Science Research, 6(1), 7-15.https://doi.org/10.46281/aijssr.v6i1.930

Himat, A. N., Takal, M. H., \& Hakimi, M. F. (2021). AFGHAN STUDENTS'SATISFACTION FROM ONLINE LEARNING DURING COVID-19 AT KANDAHAR UNIVERSITY, KANDAHAR, AFGHANISTAN. American International Journal of Social Science Research, 6(1), 16-29.https://doi.org/10.46281/aijssr.v6i1.931

Jolibert, A., \& Baumgartner, G. (1997). Values, motivations, and personal goals: Revisited. Psychology \& Marketing, 14(7), 675-688.

Mazzarol, T. (1998). Critical success factors for international education marketing. International Journal of Educational Management. https://doi.org/10.1108/09513549810220623

Mazzarol, T., \& Soutar, G. N. (2002). "Push-pull” factors influencing international student destination choice. International Journal of Educational Management. https://doi.org/10.1108/09513540210418403

McGiffert, C. (2011). 100,000 strong: Building strategic trust in US-China relations through education. IIE Networker, 2122.

McMahon, M. E. (1992). Higher education in a world market. Higher education, 24(4), 465482. https://doi.org/10.1007/BF00137243 
Nazari, H. R., \& Himat, A. N. (2020). The Usage of Peer Feedback and its Influence on Afghan EFL Learners' Academic Achievement at Kandahar University Afghanistan. London Journal of Research in Humanities and Social Sciences 20(1), 35-46.

Sahibzada, J., \& Himat, A. N. (2019). Impacts of Formative Assessment on EFL Students' Academic Performance at Kandahar University. American International Journal of Social Science Research, 4(2), 102-111.https://doi.org/10.46281/aijssr.v4i2.368

Sánchez, C. M., Fornerino, M., \& Zhang, M. (2006). Motivations and the intent to study abroad among US, French, and Chinese students. Journal of Teaching in International Business, 18(1), 27-52. https://doi.org/10.1300/J066v18n01_03

Sirowy, L., \& Inkeles, A. (1985). 2. University-level Student Exchanges: The US Role in Global Perspective. Hoover Institution on War, Revolution, and Peace.

Smith, D. E., \& Mitry, D. J. (2008). Benefits of study abroad and creating opportunities: The case for short-term programs. Journal of Research in Innovative Teaching, 1(1), 236246.

Teichler, U., \& Steube, W. (1991). The logics of study abroad programmes and their impacts. Higher Education, 21(3), 325-349. https://doi.org/10.1007/BF00132724

\section{Copyrights}

Copyright for this article is retained by the author(s), with first publication rights granted to the journal. This is an open-access article distributed under the terms and conditions of the Creative Commons Attribution license (http://creativecommons.org/licenses/by/4.0/) 